\title{
Comparison of hepatoprotective effect of aqueous and ethanolic extracts of Berberis lycium Royle (Sumbloo) in isoniazid induced hepatotoxicity in male mice model
}

\author{
Saima Rafique ${ }^{1 *}$, Khalida Ajmal ${ }^{1}$, Uzma Naeem², Akbar Waheed ${ }^{2}$, \\ Ayesha Afzal $^{1}$, Attiya Munir ${ }^{3}$, Iffat Ara ${ }^{1}$
}

\author{
${ }^{1}$ Department of Pharmacology and Therapeutics, Wah Medical College, Wah Cantt, Pakistan \\ ${ }^{2}$ Department of Pharmacology and Therapeutics, Islamic International Medical College, Islamabad, Pakistan \\ ${ }^{3}$ Department of Pharmacology and Therapeutics, Rawaplindi Medical University, Rawalpindi, Pakistan
}

Received: 21 April 2020

Accepted: 11 May 2020

*Correspondence:

Dr. Saima Rafique,

Email: saimarafiqu34@gmail.com

Copyright: (C) the author(s), publisher and licensee Medip Academy. This is an open-access article distributed under the terms of the Creative Commons Attribution Non-Commercial License, which permits unrestricted non-commercial use, distribution, and reproduction in any medium, provided the original work is properly cited.

\begin{abstract}
Background: The objective of the study was to compare the hepatoprotective effect of aqueous and ethanolic extracts of stem bark of Berberis lycium Royle in isoniazid (INH) induced hepatotoxicity in mice model.

Methods: This randomized controlled in-vivo study conducted in male mice model from 10th April 2014 till 10th May 2014 at National Institute of Health, Islamabad. Group (C) was given normal diet and water. Group (D) was given isoniazid $(50 \mathrm{mg} / \mathrm{kg} \mathrm{BW})$ to produce hepatotoxicity. Group (LA) and (HA) were given isoniazid (INH) plus low and high dose of aqueous extract of stem bark of Berberis lycium Royle respectively. Group (L.E) and (H.E) were given INH plus low and high dose of ethanolic extract of stem bark of Berberis lycium Royle respectively.

Results: Hepatotoxicity produced by INH was shown by raised serum liver function tests (LFT's), marked hepatocytic ballooning, significant steatosis and inflammation. Mice receiving simultaneous treatment of INH, low and high dose of aqueous extract of Berberis lycium Royle showed decrease serum LFT's and their liver sections showed improved histological picture but more significant reduction in hepatotoxic effects were observed in animals receiving low and high doses of ethanolic extract.

Conclusions: Hepatotoxicity of INH can be more fully reversed by simultaneous use of INH with ethanolic extract as it has better hepatoprotective potential in dose dependent manner as compare to aqueous extract of stem bark of Berberis lycium Royle.
\end{abstract}

Keywords: Berberis lycium Royle, Aqueous extracts, Ethanolic extracts, Hepatoprotective, Isoniazid, LFT's

\section{INTRODUCTION}

Mycobacterium tuberculosis is the most prevalent cause of tuberculosis worldwide. It has proven to be one of the most notorious pathogens in the history of mankind. ${ }^{1}$ Tuberculosis (TB) currently is one of the leading cause of death globally by infecting one-third of population all over the world. ${ }^{2}$ Isoniazid (INH) made its place as a cornerstone in the treatment of tuberculosis since $1952 .{ }^{3} \mathrm{INH}$ has proven its efficacy to be used as anti-tuberculous dug. ${ }^{4}$ Hepatotoxicity is one of the major adverse effect encountered by isoniazid during anti-tuberculous therapy. ${ }^{5}$

INH metabolism is responsible for INH-induced liver injury. Most common biochemical mechanism is metabolism of INH into reactive metabolites that bind and damage the macromolecules in hepatocytes. Acetylation of INH in liver produces acetyl INH which is further 
oxidized to either hydroxylamine which is a toxic metabolite or hydrolyzed into hydrazine which is also toxic and further hydrolyzed to another noxious compound i.e. acetyl hydrazine. ${ }^{6}$ INH induced hepatotoxicity is diagnosed by raised serum liver function tests (LFT's) such as aspartate aminotransferase (AST), alanine aminotransferase (ALT), alkaline phosphatase (ALP) and total bilirubin). ${ }^{7}$ Hepatotoxicity produced by INH is proven by observing inflammatory infiltrates, steatosis and hepatocytic ballooning. ${ }^{8,9}$

Previous research studies have shown hepatoprotective effect of extracts of Berberis lycium Royle in combination with other herbs. ${ }^{10}$ No research study has been carried out as yet on comparison of aqueous and ethanolic extract of Berberis lycium Royle in perspective of hepatoprotective effect. Our study was planned to compare the hepatoprotective effect of low and high doses of ethanolic extract with low and high doses of aqueous extract of stem bark of Berberis lycium Royle by estimating serum LFT's and observing the microscopic histopathological changes of liver. Various research studies have proven hepatoprotective effect of Berberis lycium Royle. Berberis lycium Royle is also known for its various traditional names like Barbery, Sumbloo and Ziarlargay. ${ }^{11}$ Berberine $(4.2 \%)$ is the active constituent of stem bark of Berberis lycium Royle. ${ }^{12}$ Berberis lycium Royle has considerable hepatoprotective and hypoglycemic potential. ${ }^{13}$ It has also been used for the treatment of jaundice, rheumatism, whooping cough, ear and eye infections. ${ }^{14}$

Our objective of study was to compare the hepatoprotective effects of low and high doses of ethanolic extract with low and high doses of aqueous extract of stem bark of Berberis lycium Royle on INH induced hepatotoxicity in male mice model.

\section{METHODS}

An animal research study was conducted in animal house of National Institute of Health (NIH), Islamabad from $10^{\text {th }}$ April till $10^{\text {th }}$ May 2014. A total of eighty-four adult male albino Balb/c mice weighing 30-40 gms and having age between 7-9 weeks, with normal LFT's were included in research study. All male albino Balb/c mice were acclimatized for 7 days. Then all male albino Balb/c mice were randomly divided into six groups each group containing 14 mice $(n=14)$. group $C:(n=14)$ was the normal control group fed on normal diet and fresh water orally. Group D (drug treated group): $(n=14)$ was given INH $\left(50 \mathrm{mg} / \mathrm{kg}\right.$ body wt) only. ${ }^{15}$ Group L.A (low dose aqueous extract group): $(n=14)$ was given low dose $(150$ $\mathrm{mg} / \mathrm{Kg}$ body wt) and group H.A (high dose aqueous extract group): ( $\mathrm{n}=14)$ kept on high dose $(200 \mathrm{mg} / \mathrm{kg}$ body $\mathrm{wt})$ of aqueous extract of stem bark of Berberis Lycium Royle along with INH ( $50 \mathrm{mg} / \mathrm{kg}$ body wt). Group L.E (low dose ethanolic extract group): $(n=14)$ given low dose $(150$ $\mathrm{mg} / \mathrm{kg}$ body wt) and group H.E (high dose ethanolic extract group): $(\mathrm{n}=14)$ kept on high dose $(200 \mathrm{mg} / \mathrm{kg}$ body wt) of ethanolic extract of stem bark of Berberis Lycium
Royle along with INH (50 mg/kg body wt). Herb and the drugs were given through mouth daily consecutively for 4 weeks. Mice were kept in animal house under standardized conditions with room temperature of $22 \pm 2{ }^{\circ} \mathrm{C}$, relative humidity $55 \%$ to $75 \%$ and $12 \mathrm{~h}$ light: dark cycle. They were given free access to water ad libitum. All the mice included in research study were given care in accordance with the standardized NIH guidelines. Stem bark of the herb Berberis lycium Royle was procured from a village Prang, in Charsadda. Identification of stem bark was done by a botanist named Ghulam Jillani serving at herbarium section of botany department in Peshawar University. Stem bark of the herb was washed thoroughly with water and dried in shade. It was then crushed into a fine powder by using an electrical grinder and saved into a non-metallic jar. For aqueous extract preparation, stem bark powder was soaked for 72 hours in distilled water with intermittent stirring. Filtration of soaked bark powder was done using Whatmann filter paper no 1 . Then the filtrate was evaporated using rotary evaporator at $55{ }^{\circ} \mathrm{C}$ at the research laboratory of Riphah Institute of Pharmaceutical Sciences (RIPS), Islamabad. After the evaporation of filtrate, the extract was converted into a dark brown color semi-solid sticky paste. It was poured in air tight glass bottles, avoiding the contact to direct sunlight and stored in refrigerator at $2-8{ }^{\circ} \mathrm{C}$ for future research purpose. The aqueous extract yield of stem bark of Berberis lycium Royle with respect to the original dry plant material was about $25 \% .{ }^{16}$ For ethanolic extract preparation, dried fine powder of stem bark weighing $1 \mathrm{~kg}$ was soaked in ethanol at $25{ }^{\circ} \mathrm{C}$ for 3 days with periodic stirring. Coarse filtration of powdered stem bark soaked in ethanol was done by utilizing muslin cloth and then fine filtration done by Whatman filter paper 1. Ethanolic fine filtrate was left for dissipation in outdoors and final evaporation was done using rotary evaporator under reduced pressure at $41{ }^{\circ} \mathrm{C}$. The final obtained ethanolic extract was chocolate brown in color with semi-solid sticky consistency. Final chocolate brown color ethanolic extract was also stored in air tight glass bottles, kept in refrigerator at temperature of $2-9{ }^{\circ} \mathrm{C}$ for future use in experimental research. The ethanolic extract yield was about 20\% (20 g was obtained from $100 \mathrm{~g}) .{ }^{17}$ Two mice were sacrificed at day 0 from each group for collection of blood samples for baseline LFT's and at day 15 for appraisal of research progress. Finally, blood samples of 10 mice from each group were drawn at the last $30^{\text {th }}$ day of research for final estimation of LFT's. Cardiac puncture technique is used to collect blood samples measuring of $2 \mathrm{ml}$ in sterile vacutainer with gel. Blood samples were let to clot and bench top centrifuge machine was used to separate the serum from clotted blood samples by centrifugation at $3000 \mathrm{rpm}$ for 15 minutes. All the separated serum samples were stored in serum cups at $-20^{\circ} \mathrm{C}$ for future biochemical evaluation of LFT's. ${ }^{15} \mathrm{ALT}$, AST and ALP have been estimated via commercially reachable kits (Merck pharma) and total bilirubin via (spectrum diagnostics kit). Serum ALT, AST, was estimated through IFCC, ALP with the aid of optimized standardized technique and total bilirubin by calorimetric approach. $^{18}$ 
After taking blood samples, anesthetized mice were dissected to take out liver tissues. Liver tissues were preserved in $10 \%$ formalin and further processed for histopathological examination both qualitatively and quantitatively. Qualitatively, INH induced liver damage was recognized by change in color and surface appearance of liver on bare eye examination while steatosis, ballooning of hepatocytes and inflammatory infiltrates were observed under $40 \mathrm{X}$ objective of microscope. Semiquantitative morphological grading was achieved via using Kleiner criteria for steatosis and hepatocytic ballooning whereas modified HAI grading was specifically used for inflammatory changes.

\section{Statistical analysis}

Data was analysed using statistical package for social sciences (SPSS) version 20.0. Mean \pm SD was calculated for quantitative biochemical and histological parameters. To observe mean differences among control and experiment groups one-way analysis of variance (ANOVA) was applied. Post hoc Tuckey test was applied to compare mean differences among the groups. $\mathrm{P}$ value was calculated using Pearson chi square test while comparing two groups. $\mathrm{P}$ value of $<0.05$ was considered statistically significant.

\section{RESULTS}

Eighty-four mice were used for the research and divided into six groups i.e., control group (C), drug treated group (D), low aqueous group (LA), high aqueous group (HA), low ethanolic group (LE) and high ethanolic group (HE) of 14 mice each $(n=14)$.

\section{Biochemical analysis on day 0}

At the start of study, blood samples of 2 mice were collected by cardiac puncture from each group for baseline estimation of liver function tests (LFTs). Results showed normal LFT's of all mice.

\section{Biochemical analysis on day $15^{\text {th }}$}

At the mid of study, blood samples of 2 mice were collected by cardiac puncture from each group for estimation of LFT's in order to assess progress of research. Results showed some derangement of LFT's.

\section{Biochemical analysis on day $30^{\text {th }}$}

On completion of research study, blood samples of all the mice of 6 groups $(n=10)$ were collected by cardiac puncture for estimation of final serum levels of LFT's.

\section{Effect of Berberis lycium Royle on serum level of total bilirubin}

Mean total bilirubin was $0.10 \pm 0.0 \mathrm{mg} / \mathrm{dl}$ in group $\mathrm{C}$, $1.26 \pm 0.069 \mathrm{mg} / \mathrm{dl}$ in group $\mathrm{D}, 0.50 \pm 0.071 \mathrm{mg} / \mathrm{dl}$ in group
LA, $0.19 \pm 0.043 \mathrm{mg} / \mathrm{dl}$ in group HA, $0.76 \pm 0.078 \mathrm{mg} / \mathrm{dl}$ in group LE and $0.16 \pm 0.034 \mathrm{mg} / \mathrm{dl}$ in group HE (Table 1). Significant difference was observed between the groups $(\mathrm{p}<0.001)$. Group C, group HA and group HE was similar to each other with insignificant difference but significantly different from all other groups (Table 2 and Figure 1).

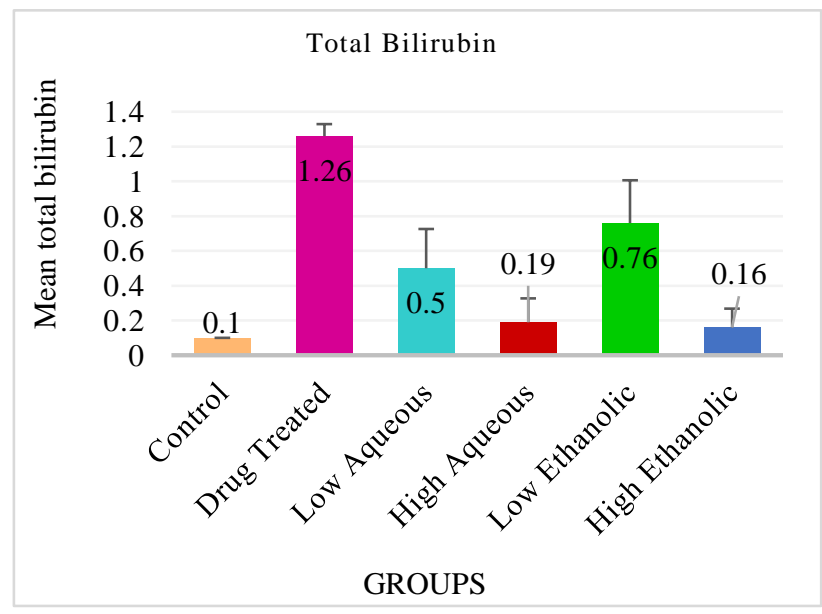

Figure 1: Comparison of total bilirubin between the groups.

\section{Effect of Berberis lycium Royle on serum level of ALT}

Mean ALT was 53 $\pm 4.99 \mathrm{U} / 1$ in group C, 183.1 $\pm 20.02 \mathrm{U} / \mathrm{l}$ in group $\mathrm{D}, 78.9 \pm 3.85 \mathrm{U} / 1$ in group LA, 58.3 $\pm 3.93 \mathrm{U} / \mathrm{L}$ in group HA, 94.6 $\pm 14.34 \mathrm{U} / 1$ in group LE and 50 $\pm 3.89 \mathrm{U} / 1$ in group HE (Table 1). Significant difference was observed between the groups $(\mathrm{p}<0.001)$. Group D had significantly higher ALT level as compared to all other groups while all other groups had almost similar ALT level (Table 2 and Figure 2).

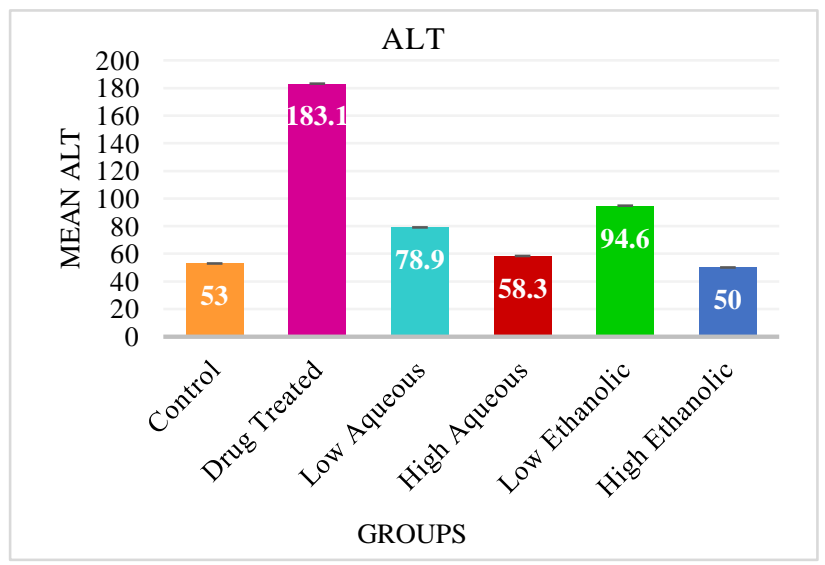

Figure 2: Comparison of ALT between the groups.

\section{Effect of Berberis lycium Royle on serum level AST}

Mean AST was 107.1 $\pm 18.46 \mathrm{U} / 1$ in group C, 428.9 \pm 55.32 $\mathrm{U} / \mathrm{l}$ in group $\mathrm{D}, 263.5 \pm 28.72 \mathrm{U} / 1$ in group LA, 117.9 \pm 16.97 $\mathrm{U} / \mathrm{l}$ in group HA, 202.3 $\pm 35.65 \mathrm{U} / 1$ in group LE and 103.4 $\pm 15.06 \mathrm{U} / 1$ in group HE (Table 1). Significant 
difference was observed between the groups $(\mathrm{p}<0.001)$. Group C, group HA, group LE and group HE was similar to each other with insignificant difference but significantly different from all other groups (Table 2 and Figure 3).

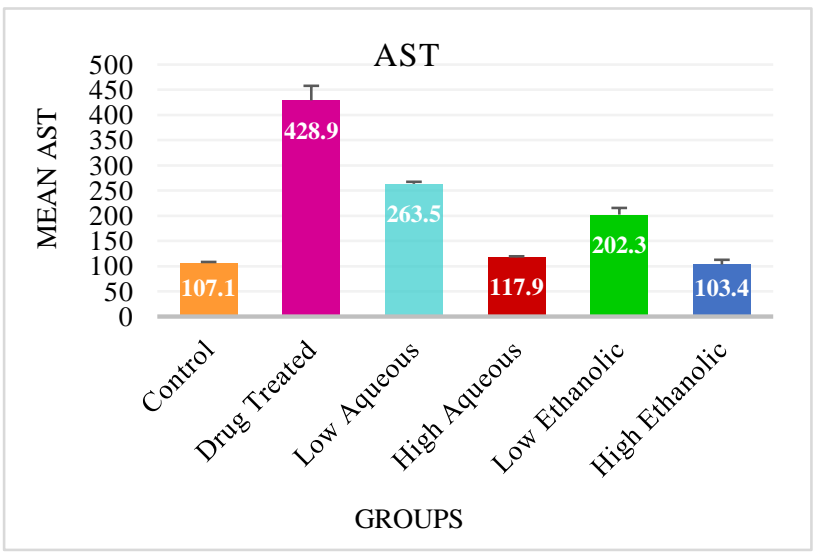

Figure 3: Comparison of AST between the groups.

\section{Effect of Berberis lycium Royle on serum level ALP}

Mean ALP was 88.6 $\pm 1.24 \mathrm{U} / \mathrm{l}$ in group C, $173.6 \pm 28.89 \mathrm{U} / \mathrm{l}$ in group $\mathrm{D}, 99.1 \pm 3.93 \mathrm{U} / 1$ in group LA, $87.8 \pm 1.66 \mathrm{U} / 1$ in group HA, $110.3 \pm 13.21 \mathrm{U} / 1$ in group LE and 89.4 $\pm 1.93 \mathrm{U} / 1$ in group HE (Table 1). Significant difference was observed between the groups $(p<0.001)$. Group D had significantly higher ALT level as compared to all other groups while all other groups were almost similar to each other (Table 2 and Figure 4).

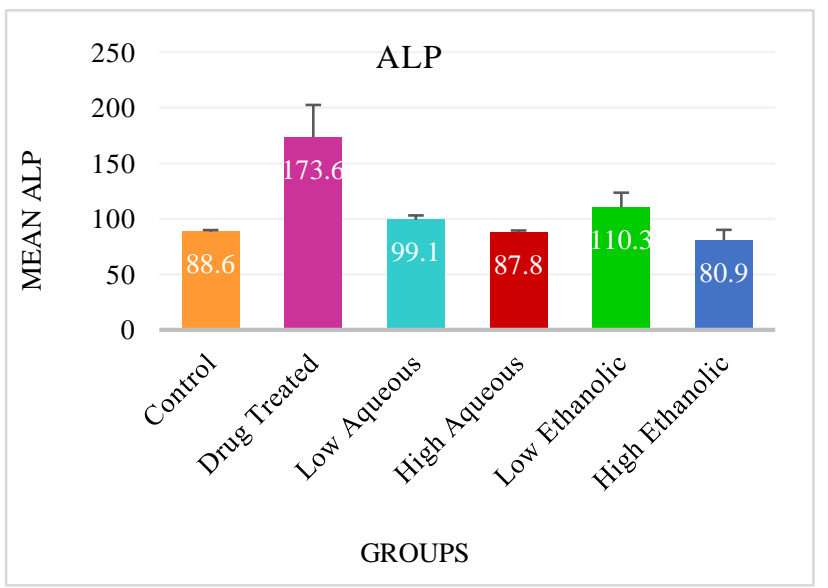

Figure 4: Comparison of ALP between the groups.

\section{Gross and histopathological examination of liver}

Gross examination of liver of control group (C) showed reddish brown color with smooth surfaces. Histopathological examination of $\mathrm{H}$ and $\mathrm{E}$ preparations of liver sections of control group (C) depicted normal lobular appearance having normal central vein and portal tract with radiating cords of hepatocytes. Portal triads were present between adjacent lobules consisting of portal vein, bile duct and the hepatic artery (Figure 5).

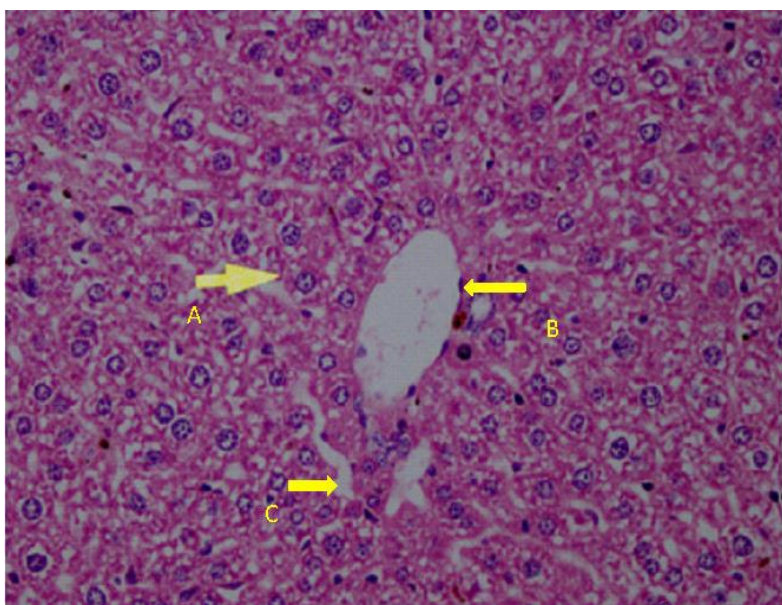

Figure 5: The thin liver section of an animal 2 of control group $\mathrm{C}$ showing, (A) hepatocytes, (B) central vein and $(C)$ sinusoid space, $H$ and $E$ stain, $40 X$.

INH given to drug treated group (D) resulted in severe hepatotoxicity by showing prominent hepatocytic ballooning, severe steatosis and heavy inflammatory infiltrates (Figure 6).

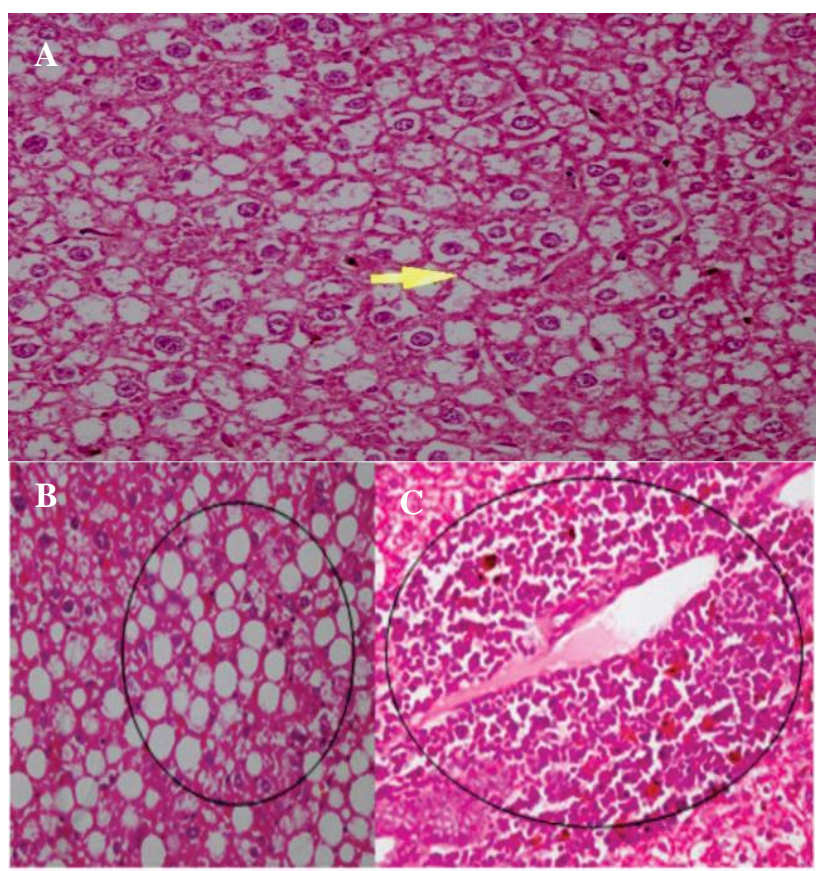

Figure 6 (A-C): Photomicrograph of thin section of liver specimen of drug treated group showing hepatocytic ballooning, severe steatosis and perivenular inflammatory infiltrate. $\mathrm{H}$ and $\mathrm{E}$ stain, 40X.

Histopathological examination of $\mathrm{H}$ and $\mathrm{E}$ preparations of thin liver sections of aqueous extract treated group showed reversal from severe to moderate perivenular and intralobular inflammation, moderate steatosis and very few ballooned cells in low dose $(150 \mathrm{mg} / \mathrm{kg})$ and mild 
inflammation, steatosis, hepatocytic ballooning in high dose treated group $(200 \mathrm{mg} / \mathrm{kg})$ (Figure 7).

Histopathological examination of $\mathrm{H}$ and $\mathrm{E}$ preparations of liver sections of ethanolic extract treated group showed reversal of severe inflammation to minimum perivenular inflammation in low dose $(150 \mathrm{mg} / \mathrm{kg})$ and absent inflammation, steatosis and hepatocytic ballooning in high dose treated group (200 mg/kg) (Figure 8).

Table 1: Comparison of total bilirubin, ALT, AST and ALP between the groups.

\begin{tabular}{|lllll|}
\hline Groups & Total bilirubin & ALT & AST & ALP \\
\hline Group C & $0.10 \pm 0.0$ & $53 \pm 4.99$ & $107.1 \pm 18.46$ & $88.6 \pm 1.24$ \\
\hline Group D & $1.26 \pm 0.069$ & $183.1 \pm 63.32$ & $428.9 \pm 55.32$ & $173.6 \pm 28.89$ \\
\hline Group LA & $0.50 \pm 0.226$ & $78.90 \pm 3.85$ & $263.5 \pm 28.72$ & $99.1 \pm 3.93$ \\
\hline Group HA & $0.19 \pm 0.137$ & $58.3 \pm 3.93$ & $117.9 \pm 16.97$ & $87.8 \pm 1.66$ \\
\hline Group LE & $0.76 \pm 0.246$ & $94.6 \pm 14.34$ & $202.3 \pm 35.65$ & $110.3 \pm 13.21$ \\
\hline Group HE & $0.16 \pm 0.108$ & $50 \pm 3.89$ & $103.4 \pm 15.06$ & $80.9 \pm 9.18$ \\
\hline p value & $<0.001^{*}$ & $<0.001 *$ & $<0.001 *$ & $<0.001 *$ \\
\hline
\end{tabular}

Values are expressed as mean $\pm \mathrm{SD}, *=$ Significant.

Table 2: Post-hoc comparison of total bilirubin, ALT, AST and ALP between the groups.

\begin{tabular}{|c|c|c|c|c|c|c|c|c|}
\hline \multirow{2}{*}{$\begin{array}{l}\text { Group } \\
\text { comparison }\end{array}$} & \multicolumn{2}{|c|}{ Total bilirubin } & \multicolumn{2}{|l|}{ ALT } & \multicolumn{2}{|l|}{ AST } & \multicolumn{2}{|l|}{ ALP } \\
\hline & $\begin{array}{l}\text { Mean } \\
\text { difference }\end{array}$ & P value & $\begin{array}{l}\text { Mean } \\
\text { difference }\end{array}$ & $P$ value & $\begin{array}{l}\text { Mean } \\
\text { difference }\end{array}$ & $P$ value & $\begin{array}{l}\text { Mean } \\
\text { difference }\end{array}$ & $P$ value \\
\hline $\begin{array}{l}\text { Group C vs } \\
\text { Group D }\end{array}$ & -1.16 & $<0.001 *$ & -130.1 & $<0.001 *$ & -321.8 & $<0.001 *$ & -85.0 & $<0.001 *$ \\
\hline $\begin{array}{l}\text { Group C vs } \\
\text { Group LA }\end{array}$ & -0.40 & $<0.001 *$ & -25.9 & 0.522 & -156.4 & $0.008 *$ & -10.5 & 0.993 \\
\hline $\begin{array}{l}\text { Group C vs } \\
\text { Group HA }\end{array}$ & -0.09 & 0.855 & -5.30 & 0.999 & -10.8 & 1.000 & 0.8 & 1.000 \\
\hline $\begin{array}{l}\text { Group C vs } \\
\text { Group LE }\end{array}$ & -0.66 & $<0.001 *$ & -41.6 & 0.078 & -95.2 & 0.247 & -21.7 & 0.849 \\
\hline $\begin{array}{l}\text { Group C vs } \\
\text { Group HE }\end{array}$ & -0.06 & 0.974 & 3.0 & 1.000 & 3.7 & 1.000 & -0.8 & 1.000 \\
\hline $\begin{array}{l}\text { Group D vs } \\
\text { Group LA }\end{array}$ & 0.76 & $<0.001 *$ & 104.2 & $<0.001 *$ & 165.4 & $0.004 *$ & 74.5 & $0.002 *$ \\
\hline $\begin{array}{l}\text { Group D vs } \\
\text { Group HA }\end{array}$ & 1.07 & $<0.001 *$ & 124.8 & $<0.001 *$ & 336.7 & $<0.001 *$ & 85.8 & $<0.001 *$ \\
\hline $\begin{array}{l}\text { Group D vs } \\
\text { Group LE }\end{array}$ & 0.50 & $<0.001 *$ & 88.5 & $<0.001 *$ & 226.6 & $<0.001 *$ & 63.3 & $0.015^{*}$ \\
\hline $\begin{array}{l}\text { Group D vs } \\
\text { Group HE }\end{array}$ & 1.10 & $<0.001 *$ & 133.1 & $<0.001^{*}$ & 355.7 & $<0.001 *$ & 84.2 & $<0.001 *$ \\
\hline $\begin{array}{l}\text { Group LA vs } \\
\text { Group HA }\end{array}$ & 0.31 & $0.003^{*}$ & 20.6 & 0.744 & 171.3 & $0.003^{*}$ & 11.3 & 0.990 \\
\hline $\begin{array}{l}\text { Group LA vs } \\
\text { Group LE }\end{array}$ & -0.26 & $0.022 *$ & -15.7 & 0.900 & 61.2 & 0.712 & -11.2 & 0.990 \\
\hline $\begin{array}{l}\text { Group LA vs } \\
\text { Group HE }\end{array}$ & 0.34 & $0.001 *$ & 28.9 & 0.399 & 190.3 & $0.001 *$ & 9.7 & 0.995 \\
\hline $\begin{array}{l}\text { Group HA vs } \\
\text { Group LE }\end{array}$ & -0.57 & $<0.001 *$ & -36.3 & 0.169 & -110.1 & 0.124 & -22.5 & 0.829 \\
\hline $\begin{array}{l}\text { Group HA vs } \\
\text { Group HE }\end{array}$ & 0.03 & 0.999 & 8.3 & 0.994 & 14.5 & 0.999 & -1.6 & 1.000 \\
\hline $\begin{array}{l}\text { Group LE vs } \\
\text { Group HE }\end{array}$ & 0.60 & $<0.001 *$ & 44.6 & $0.048 *$ & 129.1 & $0.044^{*}$ & 20.9 & 0.868 \\
\hline
\end{tabular}

*=Significant. 


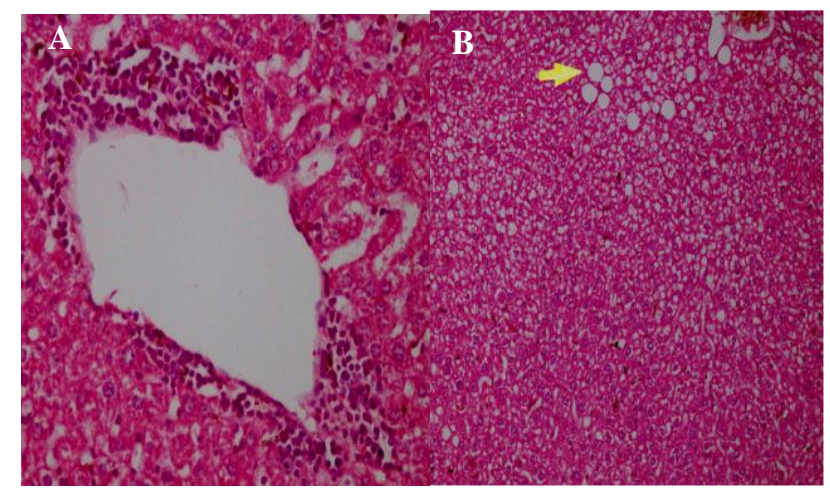

Figure 7 (A and B): Photomicrograph of section of liver specimen of low aqueous extract treated group showing mild portal inflammation. $\mathrm{H}$ and $\mathrm{E}$ stain, 40X.

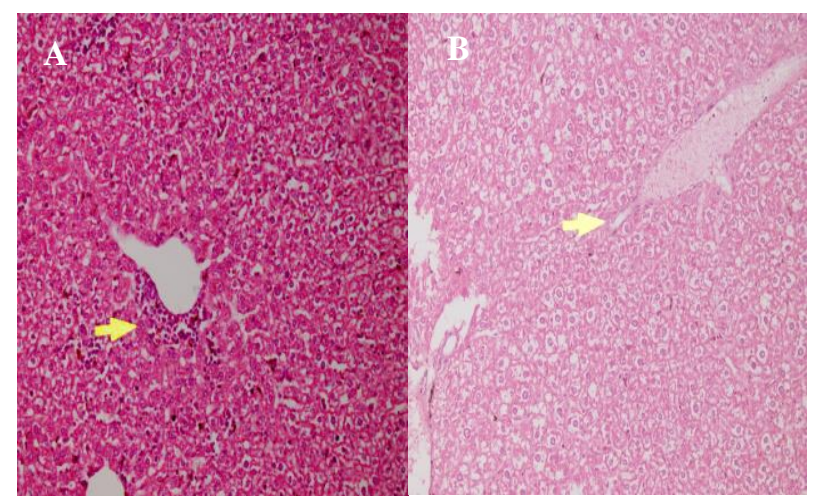

Figure 8 (A and B): Photomicrograph of low ethanolic (L.E) extract treated group showing minimum perivenular inflammation and high ethanolic (H.E) extract treated group showing absent steatosis, inflammation and hepatocytic ballooning. $\mathrm{H}$ and $\mathrm{E}$ stain, 40.

\section{DISCUSSION}

Drug induced hepatotoxicity (DIH) of anti-tubercular drugs is a major adverse effect because it results in high mortality and morbidity. INH hepatotoxicity is a frequent complication of anti-tuberculous drug therapy that may differ in severity from asymptomatic elevation of LFT's to severe hepatotoxicity resulting in hepatic failure that may require even liver transplantation. ${ }^{19}$ Hepatotoxicity due to anti-tubercular drugs is found to be mediated through direct toxicity of the compound or its metabolite, oxidative stress, immune mediated injury, free radical damage and hypersensitivity reactions. ${ }^{20,21}$ Massive reactive species derived from oxygen may also lead to oxidative damage to liver tissue. Oxidative stress has been proven as one of the main mechanisms to initiate liver injury. The use of antioxidants is considered therapeutically significant for the cure of oxidative stress induced liver injury. ${ }^{22}$ For T.B such a treatment option is required which may reduce the drug induced liver injury (DILI). ${ }^{23}$ Herbal medicine has been found to be an area of great interest since ancient times owing to its relatively better safety profile.
Medicinal plants have been shown to exert antiinflammatory, anti-stress and anti-cancer effects by modulating the immune function. ${ }^{24}$

Among many of the herbs, Berberis lycium Royle, is found to be hepatoprotective. ${ }^{25}$ Berberis lycium is broadly used for the cure of various ailments. Herb consists of major alkaloid berberine. ${ }^{26}$ Berberine is hepatoprotective due to its antioxidant properties. Antioxidant properties are due to its capability to quench 1,1-diphenyl-1-picrylhydrazyl free radicals, reduce the leakage of lactate dehydrogenase (LDH), alanine transaminase (ALT) and avoid the formation of malondialdehyde induced by tert-butyl hydroperoxide. ${ }^{27}$ Hepatoprotective effect may be due to the flavonoids or polyphenolic compounds, which are ethanol soluble and present in many herbs. Flavonoids and polyphenolic compounds have strong antioxidant activity, which have hepatoprotective role against free radical injury. ${ }^{28}$

Our study was designed to compare the hepatoprotective effect of aqueous as well as ethanolic extract of stem bark of Berberis lycium Royle.

Our research study results showed that aqueous extract of stem bark of Berberis lycium Royle has considerable hepatoprotective potential $(\mathrm{p}<0.001)$ in dose-dependent manner. High dose of aqueous extract $(200 \mathrm{mg} / \mathrm{kg}$ body wt) restored ALT, AST, ALP and total bilirubin (LFT's) to a higher extent as in contrast to low dose $(150 \mathrm{mg} / \mathrm{kg}$ body wt). Significant elevation was observed in levels of serum ALP, AST, ALT and total bilirubin in group D which was given INH as compare to group $\mathrm{C}$ mice which received no medications. Increased serum levels of (LFT's) are diagnostic markers of liver injury. ${ }^{29}$ Collective administration of high dose $(200 \mathrm{mg} / \mathrm{kg}$ ) Berberis lycium Royle aqueous extract with INH almost normalized the ALP, AST, ALT and serum total bilirubin as compared to drug treated group (D). It is supposed most likely due to anti-oxidant effect of stem bark of Berberis lycium Royle. Khan and his colleagues in 2011 observed similar hepatoprotective activity of aqueous extract of Berberis lycium Royle in combination with Gallium aparine and Pistacia Integerrima in $\mathrm{Ccl} 4$ treated rabbits. ${ }^{16}$ The ethanolic extract of Berberis lycium Royle produced greater hepatoprotection as compared to aqueous extract showing markedly reduced levels of LFT's with low dose $(150 \mathrm{mg} / \mathrm{kg}$ ) Berberis lycium Royle and significant restoration to normal values with high dose $(200 \mathrm{mg} / \mathrm{kg})$ of stem bark of Berberis lycium Royle. Ahmed et al in 2008 found similar results while doing study on crude powder and methanolic extract of Berberis lycium Royle by paracetamol induced hepatotoxicity in rabbits. ${ }^{30}$ The ethanolic extract was more effective than aqueous extract, but both of the extracts showed significant results compared with the control group. Our study results were also found in concordance with research done by Ahmed in 2009 on Berberis lycium Roale and analysis of its extracts for bioactivity showing higher wound healing and 
antimicrobial activities of ethanolic and methanolic extract of root bark as compare to aqueous extract. ${ }^{31}$ No histopathological studies of liver specimens have been done to compare the hepatoprotective role of aqueous and ethanolic extracts of Berberis lycium Royle. In our research study there was fatty appearance and yellowish discoloration of liver specimens in drug treated group (D) given INH. Imber in 2002 recorded similar observations while performing research on hepatic steatosis and its relationship to liver transplantation. ${ }^{32}$ Steatosis is the hall mark of drug induced liver injury (DILI). In our research study moderate to severe steatosis was noticed in most of the male albino Balb/c mice of drug treated group (D) (Figure 6). Church et al in 2014 also observed similar steatotic changes by INH while performing research on mouse diversity panel identifying the role of genetic differences prompting INH-induced micro-vesicular steatosis by lipid retention in livers. ${ }^{33}$ Mice given aqueous extract of Berberis lycium Royle exhibited reverse steatotic changes produced by INH giving proof of hepatoprotective potential in experimental groups. The ethanolic extract was more effective than aqueous extract, but both of the extracts showed significant results $(\mathrm{p}<0.001)$ compared with the control group. Ahmed et al in 2009 also observed greater effects of methanolic and ethanolic extract of root bark of Berberis lycium Royle as compare to its aqueous extract while doing research for their wound healing and antimicrobial activities. ${ }^{31}$

Hepatocytic ballooning is used as an essential diagnostic marker to differentiate simple steatosis from

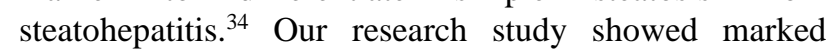
hepatocytic ballooning in drug treated group (D) which received INH only. Figure 6, showing positive correlation with the research done by Hassan in 2012 on the effect of Nigella sativa (black seeds) in INH induced hepatotoxicity in rabbits. ${ }^{35}$ Our study results showed that aqueous and ethanolic extract of Berberis lycium Royle significantly reversed hepatocytic ballooning with best reversal in ethanolic extract treated group as compare to aqueous extract treated group.

Group D given only INH revealed severe inflammation in hepatocytes showing great similarity with the research done by Hassan in 2012 while inducing hepatotoxicity in rabbit by using INH. Our research results indicate that aqueous and ethanolic extract of Berberis lycium Royle significantly reverse inflammatory changes $(\mathrm{p}<0.001)$ with best reversal obtained with high dose $(200 \mathrm{mg} / \mathrm{Kg}$ body wt) ethanolic group (H.E) showing absent inflammation in $10 \%$ of cases and minimal inflammation in $90 \%$ of cases $(\mathrm{p}<0.001)$ (Figure 8). Our experimental results were found in great correlation with work done by Ahmed in 2009 while doing research work on root bark of Berberis lycium Royle and analysis of its extracts for bioactivity showing higher antimicrobial and wound healing activities of methanolic and ethanolic extracts as compare to its aqueous extract. ${ }^{31}$ Histopathological variations induced by INH were greatly restored after giving aqueous and ethanolic extract of Berberis lycium Royle. Antioxidant properties of flavonoids present in Berberis lycium Royle may be responsible for its hepatoprotective activity. ${ }^{36}$ Our research study results were found in great accordance with work done by Rehman which showed anti-oxidant potential of methanolic extract of root bark of Berberis lycium. Antioxidant activity may be accredited to the presence of phytochemicals such as bioflavins and flavonoids. ${ }^{17}$ No study has been done to compare the hepatoprotective effect of ethanolic and aqueous extract of stem bark of Berberis lycium Royle. Our research results proved the hepatoprotective effect of aqueous and ethanolic extracts of stem bark of Berberis lycium Royle.

\section{CONCLUSION}

Our comparative research study has proven that although aqueous extract of stem bark of Berberis lycium Royle has significant hepatoprotective potential in dose dependent manner but ethanolic extract of stem bark of Berberis lycium Royle has far greater hepatoprotective potential than aqueous extract in INH induced hepatotoxicity in male mice model in a dose dependent manner.

\section{ACKNOWLEDGEMENTS}

We are grateful to Riphah International University, Pakistan for providing financial grant for this research study.

\section{Funding: Riphah International University, Pakistan Conflict of interest: None declared}

Ethical approval: The study was approved by the Institutional Review Committee, IRC

\section{REFERENCES}

1. Jagielski T, Minias A, Ingen VJ, Rastogi N, Brzostek A, Zaczek A, et al. Methodological and clinical aspects of the molecular epidemiology of Mycobacterium tuberculosis and other mycobacteria. Clin Microbiol Rev. 2016;29(2):239-90.

2. Phelan E, Gammal EA, Connor OTM. Tuberculosis. In: Encyclopedia of Environmental Health; 2019.

3. Murray JF, Schraufnagel DE, Hopewell PC. Treatment of tuberculosis: a historical perspective. Annals Am Thoracic Society. 2015;12(12):1749-59.

4. Jenkin G, Sheffield D. Isoniazid, In: Kucers the Use of Antibiotics: A Clinical Review of Antibacterial, Antifungal, Antiparasitic, and Antiviral Drugs, Seventh Edition; 2017.

5. Isa SE, Ebonyi AO, Shehu NY, Idoko P, Okopi AJA, Simji G, et al. Antituberculosis drugs and hepatotoxicity among hospitalized patients in Jos, Nigeria. Int J Mycobacteriology. 2016;5(1):21-6.

6. Wang P, Pradhan K, Zhong XB, Ma X. Isoniazid metabolism and hepatotoxicity. Acta Pharmaceutica Sinica B. 2016;6(5):384-92. 
7. Amir M, Khan MA, Ahmad S, Akhtar M, Mujeeb M, Ahmad A, et al. Ameliorating effects of Tamarindus indica fruit extract on anti-tubercular drugs induced liver toxicity in rats. Nat Prod Res. 2016;30(6):715-9.

8. Gourishankar A, Navarro F, Roy DAN, Smith KC. Isoniazid hepatotoxicity with clinical and histopathology correlate. Ann Clin Lab Sci. 2014;44(1):87-90.

9. Jahan S, Imran S, Ahsan N. Isoniazid Induced Liver Damage. Prof Med J. 2018;25(07):1124-8.

10. Kilmer PD. Book review: development theory and practice: critical perspectives. J Theory Pract Crit. 2010;11(3):369-73.

11. Murad W, Ahmad A, Gilani SA, Khan MA. Indigenous knowledge and folk use of medicinal plants by the tribal communities of Hazar Nao forest, Malakand district, North Pakistan. J Med Plants Res. 2011;58(4):697-704.

12. Id A, Author C. Antimicrobial and Anti-inflammatory Activities of Bark of Four Plant Species from Indian Origin Antimicrobial and Anti-inflammatory Activities of Bark of Four Plant Species from Indian Origin. Evid Based Complement Alternat Med. 2012;2012:1-14.

13. Yin J, Zhang H, Ye J. Traditional Chinese Medicine in Treatment of Metabolic Syndrome. Endocrine, Metab Immune Disord Targets. 2008;8(2):99-111.

14. Girish C, Koner BC, Jayanthi S, Rao RK, Rajesh B, Pradhan SC. Hepatoprotective activity of picroliv, curcumin and ellagic acid compared to silymarin on paracetamol induced liver toxicity in mice. Fundam Clin Pharmacol. 2009;23(6):735-45.

15. Basheer AS, Siddiqui A, Paudel YN, Hassan MQ, Imran M, Najmi AK, et al. Hepatoprotective and antioxidant effects of fish oil on isoniazid-rifampin induced hepatotoxicity in rats. Pharma Nutrition. 2017;5(1):29-33.

16. Khan MA, Jehanzeb, Shafiullah, Malik SA, Shafi M. Hepatoprotective effects of berberis lycium, galium aparine and pistacia integerrima in carbon tetrachloride (CCL4)-treated rats. JPMI - J Postgrad Med Inst. 2008;22(2):91-4.

17. Mashwani ZR, Khan MA, Irum S, Ahmad M. Antioxidant potential of root bark of Berberis lycium Royle. from Galliyat, western Himalaya, Pakistan. Pakistan J Bot. 2013;45:231-4.

18. Young DS. Effects of drugs on clinical laboratory tests. Am Association Clin Chemistry; 1995.

19. Pandit A, Sachdeva T, Bafna P. Drug-induced hepatotoxicity: a review. J Appl Pharm Sci. 2012;2(5):233-43.

20. Zuberi BF, Zuberi FF, Bader N, Alvi H, Salahuddin J. Comparison of British Thoracic Society and American Thoracic Society reintroduction guidelines for antituberculous therapy induced liver injury. J Pak Med Assoc. 2014;64(8):896-9.

21. Nahid P, Dorman SE, Alipanah N, Barry PM, Brozek JL, Cattamanchi A, et al. Official American thoracic society/centers for disease control and prevention/infectious diseases society of America clinical practice guidelines: treatment of drugsusceptible tuberculosis. Clin Infect Dis. 2016;63(7):147-95.

22. Li S, Tan HY, Wang N, Zhang ZJ, Lao L, Wong CW, et al. The role of oxidative stress and antioxidants in liver diseases. Int J Mol Sci. 2015;16(11):26087-124.

23. Zumla A, Chakaya J, Centis R, Ambrosio DL, Mwaba $P$, Bates $M$, et al. Tuberculosis treatment and management: an update on treatment regimens, trials, new drugs, and adjunct therapies. Lancet Respir Med. 2015;3(3):220-34.

24. Hoareau L, DaSilva EJ. Medicinal plants: a reemerging health aid. Electron J Biotechnol. 1999;2(2):3-4.

25. Jabeen N, Saleem A, Anwaar S, Hussain Z. Berberis lycium Royle (Royle, 1837): a threatened medicinal plant and Its biological activities. EC Agric. 2015;1(2):100-8.

26. Chand N, Durrani FR, Ahmad S, Khan A. Immunomodulatory and hepatoprotective role of feedadded Berberis lycium in broiler chicks. J Sci Food Agric. 2011;91(10):1737-45.

27. Hwang JM, Wang CJ, Chou FP, Tseng TH, Hsieh YS, Lin WL, et al. Inhibitory effect of berberine on tertbutyl hydroperoxide-induced oxidative damage in rat liver. Arch Toxicol. 2002;76(11):664-70.

28. Ojo OA, Oloyede OI, Olarewaju OI, Ojo AB, Ajiboye BO, Onikanni SA. In-vitro antioxidant and free radical scavenging activities of Ocimum Gratissimum. Wr J Pharma Res. 2013;2(6):1899-912.

29. Fayed AHM, Salama AAA, Ismaiel IE, Attia TA, Hassan A. Protective Effects of Solanium Nigrum Methanolic Extract Against Isoniazid/Rifampicin Induced Hepatotoxicity in Rats. J Appl Vet Sci. 2019;4(2):52-61

30. Ahmad M. Hepato-curative effect of barriers lycium (Royle) in hepatotoxic rabbits. Gomal Univ J Res. 2008;24(1):1-9.

31. Ahmed A. Biochemical Studies on Berberis Lyceum Royal and Analysis of its Extracts for Bioactivity. Arid Agriculture University Rawalpindi, Pakistan; 2009.

32. Imber CJ, Peter SD, Handa A, Friend PJ. Hepatic steatosis and its relationship to transplantation. Liver Transplant. 2002;8(5):415-23.

33. Church RJ, Wu H, Mosedale M, Sumner SJ, Pathmasiri W, Kurtz CL, et al. A systems biology approach utilizing a mouse diversity panel identifies genetic differences influencing isoniazid-induced microvesicular steatosis. Toxicol Sci. 2014;140(2):481-92.

34. Livadariu RM, Danila R, Ionescu L, Ciobanu D, Timofte D. Study of Biochemical and Clinical Markers in Steatohepatitis Related to Obesity. Rev Chim. 2018;69(6):1501-5.

35. Hassan AS, Ahmed JH, Haroon ASS. A study of the effect of Nigella sativa (black seeds) in isoniazid (INH)-induced hepatotoxicity in rabbits. Indian $\mathbf{J}$ Pharmacol. 2012;44(6):678. 
36. Ahmed S, Shakeel F. Voltammetric determination of antioxidant character in Berberis lycium Royel, Zanthoxylum armatum and Morus nigra Linn plants. Pak J Pharm Sci. 2012;25(3):501-7.
Cite this article as: Rafique $\mathrm{S}$, Ajmal K, Naeem U, Waheed A, Afzal A, Munir A, et al. Comparison of hepatoprotective effect of aqueous and ethanolic extracts of Berberis lycium Royle (Sumbloo) in isoniazid induced hepatotoxicity in male mice model. Int J Basic Clin Pharmacol 2020;9:835-43. 